http://economix.fr

Understanding the Decision Making Process of Sovereign Wealth Funds: The Case of Temasek

Document de Travail

Working Paper 2016-16

\author{
Jean-Yves Gnabo \\ Malik kerkour \\ Christelle Lecourt \\ Hélène Raymond-Feingold
}

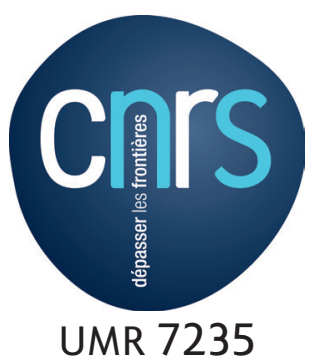

UMR 7235
Université de Paris Ouest Nanterre La Défense

(bâtiment G)

200, Avenue de la République 92001 NANTERRE CEDEX université

Paris Ouest

Nanterre La Défense 


\title{
Understanding the Decision Making Process of Sovereign Wealth Funds: The Case of Temasek ${ }^{1}$
}

\author{
J.Y. Gnabo ${ }^{\text {a }}$, M. Kerkour ${ }^{2, a}$, C. Lecourt ${ }^{\mathrm{b}}$, H. Raymond ${ }^{\mathrm{c}}$ \\ ${ }^{a}$ University of Namur, CeReFiM - Namur, Belgium \\ ${ }^{b}$ Aix-Marseille Universite, CERGAM EA 4225, 13540, Puyricard, France \\ ${ }^{c}$ University of Paris Ouest Nanterre - La Defense, France
}

\begin{abstract}
Sovereign wealth funds (SWFs) have been increasingly active over the past decade, raising concern from governments regarding their actual motives and potential cross-border stakes in national strategic sectors. The aim of this paper is to contribute to the existing literature to understand better the decisions taken by this new class of investors. the whole process of investment decision strategy is complex in the sense where it combines several dimensions that may potentially interact. For that, we investigate the economic determinants of SWF's cross-border stakes while considering the whole sequence of choices involved in this decision: (i) the decision to invest abroad or not, (ii) the decision to invest in a listed versus unlisted firm, and (iii) the decision to make large versus small investment in target company. Using a nested logit approach on one of the biggest SWF, the Singaporean fund Temasek over the 1990 to 2010 period, we provide clear evidence of dependence in the three considered levels of decision. In addition, we show that Temasek's cross-border investment probability increases with the excess of FX reserves, tends to target unlisted firms when asymmetry of information is low between the target and the home countries and involves in large stakes depending on firm financial characteristics.
\end{abstract}

JEL classification: F30, G11, G15

Keywords: Sovereign Wealth Funds; Nested Logit model; Foreign Investment

\footnotetext{
${ }^{1}$ The authors thank Bernardo Bortolloti, Marie Briere, Viviane de Beaufort, Celeste Moles Lo Turco, Michel Boutillier, Desire Omgba and Edouard Turkisch for helpful comments and remarks. The paper benefitted from reactions of attendance at the workshop on Sovereign Investment Funds and Globalization in University of Paris Ouest Nanterre. Usual disclaimers apply.

${ }^{2}$ Corresponding author. Tel.: +32 817248 81; fax: +32 81724840 .

Email addresses: jean-yves.gnabo@unamur.be (J.Y. Gnabo), malik.kerkour@unamur.be (M. Kerkour'), christelle.lecourt@univ-amu.fr (C. Lecourt), helene.raymond-feingold@u-paris10.fr (H. Raymond )
} 
"Singapore's Temasek [...] became the largest shareholder in Merrill Lynch. But concerns that their motives may be political and not just economic have prompted a backlash, with many countries such as the United States bolstering their defenses against the funds' advances" (AFP, 2008).

\section{Introduction}

Sovereign wealth funds (SWFs), defined as public investment agencies which manage part of the assets of national states resulting from excess of exchange foreign reserves, oil or gas receipts or trade surpluses, have acquired a certain notoriety in public debates in recent years, associated to the growing role they have come to play in global financial markets. If the existence of this type of investors is not new, their increasing power is a recent phenomenon, widely fed by the increase of the raw material prices (mostly the rise of the oil and gas prices) and by the development of the international economic imbalances. ${ }^{4}$ According to the 2015 Preqin Sovereign Wealth Fund Review, they represent an aggregate USD 6.31 trillion in total assets under management, growing by more than USD 900 billion since 2013. The most powerful funds, located for the main part in the countries of the Gulf and in Asia, illustrate the growth of these countries, which turned from net debtors into net creditors of industrialized countries.

While the size and rapid growth of SWFs suggest that they have become major players in the world, buying large stakes in companies and giving government's exposure to sectors they may otherwise be unable to achieve, their objectives and behavior are sometimes not well understood. The above quote on the stake of the US investment bank Merrill Lynch in 2008 by one of largest SWF in the world, the Singaporean fund Temasek, well illustrates the concern both governments and the general public may have with respect to the arrival of foreign SWFs in their country.

Following the rapid expansion of SWFs, financial economists attempted to understand better the decisions taken by this new class of investors. This task is not easy because some SWFs like for example the Asian funds or those of the Gulf are particularly opaque on their objectives or their functioning. In addition, the whole process of investment decision strategy is complex in the sense where it combines several dimensions that may potentially interact. A first important dimension regarding the SWFs investment activity concerns the determinants of investment decision: Why do SWFs invest in financial assets? In which country do they concentrate their investments? Although these questions have been extensively explored over the recent years in the empirical literature, much still need to be known to fully understand the behavior and investment strategy of this fast growing player of the financial industry. Most of studies generally try to connect the investment's decision with the characteristics of the target countries, by investigating in particular the factors driving SWF investment in foreign targets countries. Some papers assess whether these factors are macroeconomic (Amar et al., 2015), political (Avendaño and Santiso, 2009; Bernstein et al.,

${ }^{4}$ More than 25 countries have launched or proposed new SWFs since January 2008. 
2013; Dyck and Morse, 2011; Avendano, 2010; Karolyi and Liao, 2010). Other empirical studies have also stressed the link between the characteristics of the fund like for example its size, its degree of opacity, the nature of the fund (commodity versus non-commodity) and its investment decision (Knill et al., 2012b). These studies conclude that SWFs investments could be distorted by the characteristics of the fund and the targeted countries and especially by political and agency considerations.

Another dimension involved in the investment activity of SWFs pertains to the way SWFs are going to invest. Once the decision to invest or not in a particular country has been taken on a macroeconomic perspective, the way to invest is decided by the fund: In what type of firms to invest? For what amount? Existing empirical studies dealing with this dimension generally focused on the financial characteristics of the firm (for example the size and the risk of the firm) as determinant of SWF strategy (Bernstein et al., 2013; Heaney et al., 2011). In the same spirit, Knill et al. (2012b) attempt to measure the choice of SWFs for investing in public versus private global firms and show that SWFs invest not only in privately held firms, but also in privately held firms internationally. Using a Cragg Model, Knill et al. (2012a) assess the decision of SWFs to invest in a two-stage model to explain in one equation the decision of the SWFs to invest in a particular country and in the second equation to determine how much to invest.

Related to this literature and the literature on international portfolio allocation, the aim of the paper is to identify the determinants of SWF investment strategy. More specifically, we develop an approach that takes into account the fact that the decision to invest is the outcome of a complex decision making process involving successive steps. Our model is therefore designed to account for different levels of decision as well as potential interdependences between them. First, like Amar et al. (2015), we ask whether investment decision is determined by country-level characteristics. In line with Knill et al. (2012b), we then analyze the decision to invest in a listed versus unlisted firm. A final dimension concerns the study of SWF cross-border majority stake motives.

Our contribution compared to this recent literature is threefold. First, we shed light on the factors governing the decision to take a cross-border majority stake. At the notable exception of Karolyi and Liao (2010) who examine the motives for cross-border acquisition activities of government-led acquirers including SWFs, there is no or very few studies on the determinants of SWF takeovers, probably due to the unavailability of the data. We try to explain the motivation of SWFs to take a cross-border majority stake by considering the financial characteristics of the firm, the governance of the fund as well as the degree of the financial openness of the target country.

Second, contrasting with most of studies analyzing the determinants of SWF investment, we consider jointly the various steps involved in this decision : (i) the decision to invest abroad or not, (ii) the decision to invest in a listed versus unlisted firm, and eventually (iii) the decision to make large versus small investment in foreign target company. In addition, we use an empirical strategy which allows (i) to formally test the existence of interdependences across these choices and then (ii) to take into account this feature in the 
estimation procedure. More specifically, we estimate a nested logit model that allows to simultaneously identify the determinants of the investment decision, the incentives for a SWF to invest in a listed or an unlisted firm, and the variables at stake in the decision to take the control of the target firm. This methodology has the advantage to accommodate interdependence in the various dimensions of the investment decision: an element related to one dimension of the decision process can influence the outcome of another dimension. For instance, the fact that the sovereign wealth fund can take the control of a firm might influence his willingness to invest with an unlisted firm.

At last, as done in Heaney et al. (2011), we concentrate our efforts on one of the biggest SWFs namely the Singaporean fund Temasek Holdings. ${ }^{5}$ Among the bunch of SWFs that have operated over the past decade, Temasek stands out as a very interesting case as it is viewed as one of the most active SWF in financial markets and is the most transparent according to the Linaburg-Maduell Transparency index ${ }^{6}$ Considering only one fund allows us to develop a large-scale database including both data on announced cross-border stakes done by Temasek between 1989 and 2010, macroeconomic data on target countries by Temasek, as well as financial data on target firms.

Our paper has several key findings. First, we find clear evidence of interdependence between the three levels of decision we are considering. Then, we confirm that SWFs tend to invest abroad when FX reserves are positive. We also find that SWFs tend to invest in unlisted firms when asymmetry of information is low between the target country and the SWF country. At last, they involve in large stake depending on firms financial characteristics.

The plan of the remainder of this paper is as follows. In Section 2, we review the existing literature on SWFs. Section 3 presents the nested logit model which allows the investment decision to be analyzed as a sequential process. Section 4 provides some details regarding the data used in the econometric analysis while Section 5 reports and discusses the econometrics results.

\section{The existing literature}

The dramatic increase in the size of the assets managed by SWFs over the last ten years has fueled up both the media coverage and the economic literature. The literature on SWFs can be broadly classified into three groups. The first and most senior one is based on the effectiveness with which SWFs manage the wealth of their home countries (Fasano, 2000; Davis et al., 2001; Medas and Le Borgne, 2007; Brière and Bodie, 2014). These papers try to assess whether setting up a SWF enables a government either to preserve the wealth of future generations or to insulate the home economy from adverse shocks. Quite understandably

\footnotetext{
${ }^{5}$ Temasek Holdings is ranked among the world's 10th-biggest state investor and is estimated to a record value of $\$ 180$ billion of assets in March 2014. Singapore's other state investor, GIC is the 5th biggest fund with an estimated $\$ 315$ billion of assets, according to the SWF's website.

${ }^{6}$ The Linaburg-Maduell Transparency index is available in the Sovereign Wealth Funds institute at the following address: http://www.swfinstitute.org/fund-rankings/.
} 
this strand of literature has been initiated by economists from the International Monetary Fund. It was first focused on commodity SWFs that can be used either as stabilization funds or as long term investment vehicles of the proceeds of commodity exports. More recently, it has been extended by Aizenman and Glick (2008) to countries with excess foreign reserves. The second strand of literature deals with the short and long-term valuation impact of SWFs investments on the asset prices of the target firms, through the use of an event study methodology (Beck and Fidora, 2008; Fotak et al., 2008; Hesse and Sun, 2009; Raymond, 2010, 2009; Dewenter et al., 2010; Kotter and Lel, 2011; Knill et al., 2012b) or through indirect measures such as Tobin's Q (Fernandes, 2011). It developed quickly in the wake of the 2007-2008 impressive investments made by SWFs in the financial sector, that drew a lot of attention on these government controlled funds. The third group of studies on SWFs is less concerned with the assessment of whether these funds are valuecreating for the target firms and focuses instead on the determinants of their investment choices (Lyons, 2007; Balding, 2008; Aizenman and Glick, 2008; Chhaochharia and Laeven, 2008; Bernstein et al., 2013; Dyck and Morse, 2011; Knill et al., 2012b,a, 2013). In the following subsections we focus on the two last strands of the literature, as they are more closely linked to our study. Table 1 lists to the best of our knowledge the main studies devoted to sovereign wealth funds investments.

\subsection{On the value-creation of $S W F s$}

Most of the papers that try to assess whether the investments of SWFS increase the market value of the target firms use the event study methodology to measure the average reaction of the stock price of a firm after the announcement that a SWF is taking a stake in the company. These studies overwhelmingly conclude that SWF investments in publicly traded companies yield significantly positive announcement period abnormal returns (Raymond, 2009; Hesse and Sun, 2009; Karolyi and Liao, 2010; Dewenter et al., 2010; Megginson et al., 2009; Bortolotti et al., 2010; Fernandes, 2011; Kotter and Lel, 2011). Stock market investors appear to welcome the kind of long term funding liquidity provided by SWFs, as long as the stakes taken by the SWFs are not sufficiently sizable to arise fears of tunneling (Dewenter et al., 2010). However this positive short run impact appears to be quite short lived and might even turn negative in the long term.

Assessing the long term impact of the news that a SWF is taking a stake in a listed firm is a particularly delicate task, as many events affecting the valuation of the target firm may interfere over the long run. Therefore there is a scarcity of studies of long term abnormal returns following investments by SWFs. Using 802 investment news by 33 SWFs over the period 1985-2009, Bortolotti et al. (2010) conclude that target firms experience significantly negative abnormal returns over one to two years following the initial SWF investment. This conclusion is partly supported by Knill et al. (2012b) who find significant negative 1year abnormal returns when using benchmark-adjusted returns and the Fama-French four factor portfolio approach with value-weighted returns. These authors also find that the raw and benchmark adjusted stock returns of target firms decrease along with their standard deviations following SWFs acquisitions. However 


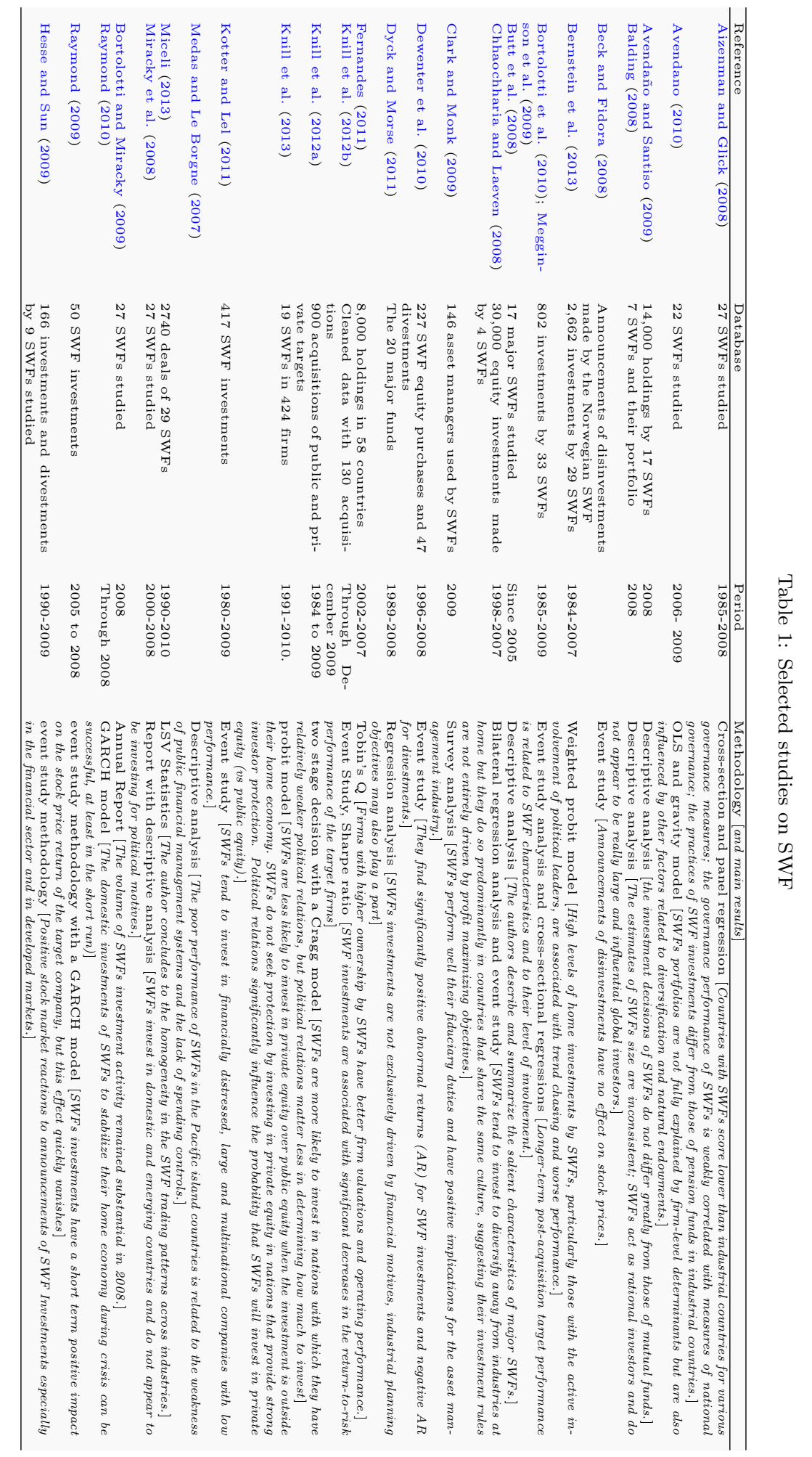


the risk is less reduced than the return, leading to a significant deterioration in the one year risk adjusted returns of firms after SWFs investments. Knill et al. (2012b) therefore conclude that the poor performance of SWFs cross border investments is consistent with the literature on government-owned firms. This poor performance may be due to the inability or unwillingness of SWFs to efficiently monitor foreign firms. It does not, however, preclude some success in SWFs domestic investments, as governments can influence the regulations in their home countries to prevent the failure of government owned domestic firms. In this respect there may be some rationale underlying the domestic investments of SWFs, which can help to explain why some SWFs play the part of domestic "investors of last resort" during crises (Raymond, 2010). Contrary to the short-term positive effect, the long term negative effect of SWFs investments on the performance target firms remains debated. Estimating target firms' Tobin's Q, Fernandes (2011) finds that firms with higher SWF ownership have better valuations and operating performances. Dewenter et al. (2010) reach a different conclusion as, according to their results, the long term stock returns of target firms go back to normal after SWFs acquisitions though there are some signs that the post-acquisition performance is positively linked with the quality of the governance of the acquiring SWF. This last result is consistent with the findings of Kotter and Lel (2011) that abnormal returns tend to increase with the transparency of the acquiring SWF, though the conclusion of these last authors is based on short term abnormal return calculations.

\subsection{On SWF investment determinants}

Another strand of the literature on SWFs investments attempts to analyze the strategies and the determinants of SWFs investment allocations, rather than testing whether SWFs are value-creating investors. These studies investigate in particular the factors driving SWFs investments in firms.

Chhaochharia and Laeven (2008) analyze how and why SWFs make their investment allocation decisions. The authors construct a large sample (about 30000 observations) of equity investments in listed and unlisted companies made by four SWFs - Norway's Government Pension Fund Global, the National Pension Reserve Fund of Ireland, the Alaska Permanent Fund and the New Zealand Superannuation Fund - over the period 1998-2007 and find that common cultural traits like religion are a determinant of these funds' investments. This suggests that the four funds studied have a tendency to "invest in the familiar" like other institutional investors. Another revealing conclusion is that these SWFs have a tendency to invest in developed markets (the United States and United Kingdom) and in financial firms, but are less present in private equity, oil and gas companies and in unethical industries. Following Chhaochharia and Laeven (2008), Dyck and Morse (2011) also consider a large set of SWF investments in international and domestic traded equities, private equities and real estate and try to explain the portfolio choices of 20 major funds. They find significant heterogeneity across funds. SWFs investments appear to be home-biased and tilted towards the financial sector. The results found by Dyck and Morse (2011) point that the motivation for SWFs investments might not be purely financial: some investments appear to be also driven by industrial planning objectives. 
Contrary to Chhaochharia and Laeven (2008) and Dyck and Morse (2011), Bernstein et al. (2013) focus on the investments of SWFs in private equity. Using a sample of 2662 investments by 29 SWFs over the period 1984-2007, the authors analyze how the funds vary in their investments styles and performance. It turns out that SWFs are more likely to invest at home (abroad) when (foreign) equity prices are higher. The funds where politicians are involved in the investment policy have a much higher likelihood of investing at home than abroad. This result suggests that SWF investments are distorted by political or agency considerations.

The results of Knill et al. (2012a) corroborate the view that political motives may play a part in the allocation of SWFs investments. They find that SWFs are more likely to invest in nations with which they have relatively weak political relations. To explore the role of political relations in the decision to invest, they use a two-stage Cragg Model. According to their results, political relations are an important factor of the choice of the investment decision in cross-border target countries but matter less in determining how much to invest. In another contribution, Knill et al. (2013) compare the determinants of an SWF's investment in private equity vs public equity with those of private institutional investors. They find that although SWFs act as other institutional investors in that they are less likely to invest in private equity over public equity when the investment is outside their domicile nation, the economic significance of this effect is less than that expected from other institutional investors. They show that SWFs do not seek protection by investing in private equity in nations that provide strong investor protection. Contrary again to institutional investors, SWFs are more likely to invest in private equity compared with public equity in countries which have weak bilateral cultural and political relations with the home country of the SWF. Overall, Knill et al. (2013) hence conclude that the determinants of SWFs investments differ significantly from those of other institutional investors, a result that contrasts with the first findings of Avendaño and Santiso (2009).

\section{The econometric approach}

\subsection{The Nested Logit Model}

What are the driving forces of sovereign wealth funds' investments? As documented in the literature, sovereign wealth funds' investments are the outcome of a complex decision process that involves several dimensions.

The aim of this paper is to contribute to the literature by shedding light on the decision making process of SWFs in general and on the determinants of cross-border majority stakes in particular. To this end, we adopt a holistic approach that considers the various dimensions involved in the process altogether. More specifically, we adopt a unified econometric framework to address the three following questions: (i) why do sovereign wealth funds invest abroad, if so (ii) why do they choose public equity rather than private equity and (iii) why do they decide to take large versus small stakes in the target firm.

Given the multiple dimensions involved, the econometric approach used to depict the SWFs' behavior has to go beyond the traditional binary choice frameworks (i.e. binary logit or probit models). Among the 
models that accommodate more than two outcomes or choices, one particular candidate is the multinomial logit one. A major drawback of this model however is that it relies on the assumption that the multiple choices to be made in order to select a specific investment are independent (i.e. independence of irrelevant alternatives (IIA) hypothesis). In accordance, the ratio of the probabilities of choosing any two alternatives should be independent of the choice set. To figure out more clearly its implication, we can take the following example. Let us consider a fund with three options of equal probability: no investment (1/3), taking a large stake $(1 / 3)$ and taking a small stake $(1 / 3)$. The probability to invest regardless of the type of investment is therefore $2 / 3$. If for any reason the fund cannot anymore take large positions in companies (i.e. the alternative large stake is no more available), the two remaining probabilities are assumed in the model to increase by the same proportion, leading the probability of investing to dramatically drop to $1 / 2$. In practice though, we expect a larger part of large stake to be converted into small stake, meaning that the fund will prefer keep on investing rather than stopping its investment activity even though it may not exceed a certain threshold of participation in companies.

\section{Table 2: Decision tree for Sovereign wealth fund}

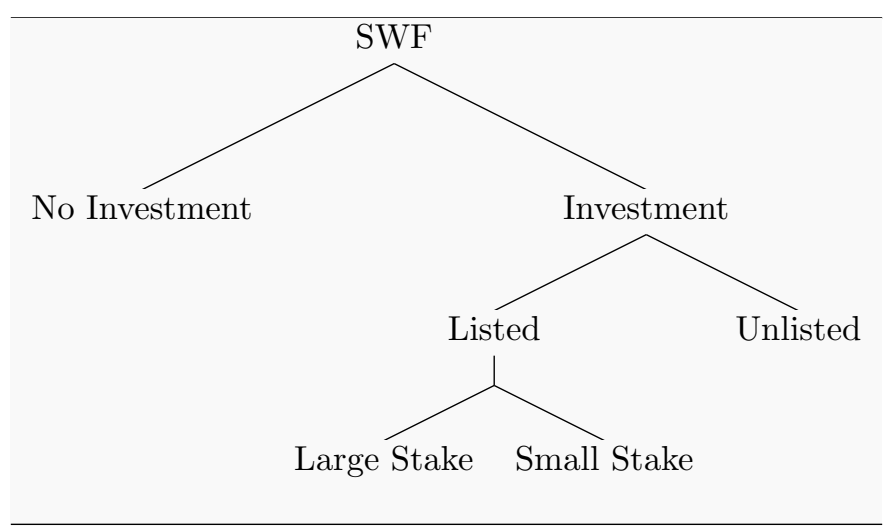

The decision tree displays the different choices embedded in the nested logit model. The first level corresponds to the decision to invest abroad or not (No investment or domestic investment). The second level explains whether the fund invests in a public/listed company (Listed) or private/unlisted company (Unlisted). The third level corresponds to the choice between large (Large Stake) or small stakes (Small Stake).

To account for both a potential deviation of the IIA hypothesis and the nature of the investment process, we use a nested logit approach (for a description see Ben-Akiva and Bierlaire, 1999). This specification captures the distinct steps involved in the investment process into a single specification: the investment decision, the choice between a listed or unlisted company, and the decision to take large versus small stake. The nested logit model relaxes the IIA assumption by allowing the different alternatives to be organized in groups and by letting within-group cross-elasticities be larger than those between groups.

As illustrated in the decision tree displayed in Figure 2, the model is partitioned into three successive 
levels corresponding to nests $(i=1, \ldots, N)$ and sub-nests $\left(j=1, \ldots, N_{i}\right)$ of alternatives $\left(k=1, \ldots, N_{i j}\right)$ : $k$ denotes whether the SWF holds a large or a small stake in a foreign company, $j$ denotes whether this company is listed (traded) or unlisted in stock exchange for public trading, at last $i$ corresponds to the decision of investing abroad or not. Each step is therefore associated with a choice between two alternatives that we aim to explain with a set of macroeconomic and financial variables.

Formally, we can describe the nested logit model as a probability problem with a probability attached to each nest. Along this line, $P_{k \mid j, i}$ is defined as the probability to take a large stake conditional on an investment in a listed company. $P_{j \mid i}$ is the probability to invest in a cross-border listed company conditional on an investment. Eventually, $P_{i}$ is the probability to invest abroad.

Using this notation, the joint probability is given by the following equation $(\mathrm{Eq}(1))$ :

$$
P_{i, j, k}=P_{k \mid j, i} \times P_{j \mid i} \times P_{i}
$$

with

$$
\begin{aligned}
P_{k \mid j, i} & =\frac{e^{\sigma_{i j}\left(\alpha X_{i j k}\right)}}{\sum_{n} e^{\sigma_{i j}\left(\alpha X_{i j n}\right)}}, \\
P_{j \mid i} & =\frac{e^{\sigma_{i}\left(\beta Z_{i j}+\frac{1}{\sigma_{i j}} I_{i j}\right)}}{\sum_{m} e^{\sigma_{i}\left(\beta Z_{i m}+\theta_{i m} I_{i m}\right)}}, \\
P_{i} & =\frac{e^{\sigma\left(\gamma W_{i}+\theta_{i} I_{i}\right)}}{\sum_{l} e^{\sigma\left(\gamma W_{l}+\theta_{i} I_{l}\right)}} .
\end{aligned}
$$

Equations 2 determine our three-levels nested logit model. The first level corresponds to the sovereign wealth fund's investment rule according to which the fund decides to invest or not. The variables included at this level, W, mainly pertain to the expected wealth of the fund (e.g. exchange rate reserve, GDP growth). The weight attached to each variable is depicted by the vector of parameters $\gamma$. The mid-level layer (listed v.s. unlisted) focuses on the type of investment chosen by the fund. The variables used at this level, denoted Z, are those described in the literature, especially in Knill et al. (2013) (e.g. geographical and cultural distance between the fund and the target company). Their effect on the probability to choose a listed company is captured by the vector of parameters $\beta$. Eventually, the bottom level corresponds to the size of the stake taken by the fund. The variables indicated by X (i.e. firm debt, return on equity) influence the willingness of the fund to take a moderate participation in the company or a large one. In line with the literature on foreign direct investment and portfolio direct investment, we consider as large investments those above $10 \%$ of the total outstanding shares of the target company. The impact of these variables is measured by the vector of parameters $\alpha$.

In addition to those parameters, the model contains two inclusive values: $I_{i j}$ and $I_{l}$. The inclusive values allow to explicitly account for dependency across the different levels of the model. As the nested logit model were originally developed as a choice model, the alternative selected by an individual at each level is assumed 
to be the one with the greater utility. This utility depends on a set of explanatory variables (see above in subsection 4.2) plus an inclusive value which incorporates lower levels information. For instance, the choice to invest in a public rather than in private equity will depend on a set of specific determinants, $\mathrm{Z}$, along with information relative to the utility of holding a large or a small stake. The latter component is factored into the model through the inclusive value, $\theta_{i} I_{l}$. Eventually, the parameter $\theta$ is the coefficient attached to this information. It therefore measures the intensity of the dependence.

\subsection{The Small-Hsiao Independence of Irrelevant Alternatives test (IIA)}

As mentioned in the previous section, an alternative to the nested logit model within the class of multivariate direct choice models is the multinomial logit one. The main difference between these two approaches lies in their underlying assumptions. Specifically, the multinomial logit model strongly relies on the independence from irrelevant alternative (IIA) hypothesis.

In order to formally assess whether this assumption holds, we use the Small and Hsiao (1985) statistical test. A rejection of the test would motivate further the use of the nested logit model rather than the multivariate logit model.

To compute this test, the sample is randomly divided into 2 subsamples of equal size, namely $S_{1}$ and $S_{2}$. The unrestricted Multinomial Logit model is estimated on both subsamples. The weighted average of the coefficient subsamples is defined as follows:

$$
{\widehat{\beta_{u}}}^{S_{1} S_{2}}=\left(\frac{1}{\sqrt{(2)}}\right){\widehat{\beta_{u}}}^{S_{1}}+\left[1-\left(\frac{1}{\sqrt{(2)}}\right)\right]{\widehat{\beta_{u}}}^{S_{2}},
$$

in which ${\widehat{\beta_{u}}}^{S_{1}}$ and ${\widehat{\beta_{u}}}^{S_{2}}$ are vectors of estimated parameters from the unrestricted model on respectively the first and the second subsample.

Next, the restricted model is constructed from the second subsample by eliminating one category. ${\widehat{\beta_{r}}}^{S_{2}}$ is the vector of estimated parameters obtained on the restricted model. Eventually, we compare the likelihood associated to the coefficient of the unrestricted and restricted models with the following statistic:

$$
S H=-2\left[L\left({\widehat{\beta_{u}}}^{S_{1} S_{2}}\right)-L\left({\widehat{\beta_{r}}}^{S_{2}}\right)\right] .
$$

If the likelihoods are substantially different, the statistic will be high, leading to a rejection of the IIA hypothesis.

\section{The data}

In this section, we detail the building of the dataset used to estimate the model described in the previous section. We start with the sources used to collect information on Temasek investments and discuss the main features of the data. Next, we turn to the description of the set of explanatory variables corresponding to each level of decision, namely $\mathrm{X}, \mathrm{Z}$ and $\mathrm{W}$ variables in the model. 


\subsection{Temasek Investment data}

One of the main challenges given to the research community on SWF is the lack of official data. Despite the slight improvement over the years, SWFs as most of financial investors have remained extremely reluctant to provide clear information either to general public or researchers on their portfolio allocation and their investment strategy more generally. To address this issue, the usual approach proposed in the literature consists in combining various sources to collect a maximum of information on SWF investment activity. Following this strategy, we construct our sample of cross-border investments done by Temasek by using two types of sources: the information extracted from three financial databases (Thomson Reuters Data Corporation's (SDC) Platinum, Zephyr and Capital IQ) and the online database Factiva which offers a wide choice of search tools and includes news reports by newswires (Dow Jones, Reuters, Business Wire and numerous publications like The Wall Street Journal or Financial Times). ${ }^{7}$ We collect a number of data items, including the stake announcement date, the target's name, its status (subsidiary, joint venture partner, private or publicly-listed company), its 4-digit Standard Industrial classification (SIC) code and the name of the country, the deal value if disclosed and the fractional stake in the target that the deal represents. Equipped with this information, we construct our dependent variables as follows: (i) we code 1 if there is evidence that Temasek has invested abroad within a month and 0 otherwise, (ii) we code 1 if this investment has been made in a listed company and 0 otherwise, eventually (iii) we code one if the investment is large and 0 otherwise. In line with the Foreign Direct Investments (FDI) literature, we consider a stake as large if it is greater than $10 \%$, which is matching with the World Banks definition of FDI: "Foreign direct investment are the net inflows of investment to acquire a lasting management interest (10 percent or more of voting stock) in an enterprise operating in an economy other than that of the investor".

Table 3 presents summary statistics - overall and by year - on the number of investments done by Temasek by distinguishing the number of domestic and foreign investments, the number of cross-border investments with a stake between $0 \%$ and less than $10 \%$, between $10 \%$ and less than $50 \%$ and between $50 \%$ and $100 \%$. Eventually last columns in Table 3 give the number of investments in listed and unlisted target firms.

The Singaporean fund Temasek holdings has been very active over the considered period with 291 acquisitions in public and private target firms. This fund has an investment strategy clearly oriented towards the international, with 229 cross-border stakes (79\% of total investments of this fund) and only 62 domestic investments (21\% of the total investments) over the period, which justifies the fact that we concentrate the first level of the nested logit model on cross-border investments. More than $72 \%$ of the foreign transactions were after 2002 and more than $30 \%$ of the foreign transactions have been done between 2007 and 2010 .

\footnotetext{
${ }^{7}$ The confrontation of these various sources allowed us to have the most complete database. Furthermore, we extract direct transactions of Temasek Holdings as well as transactions involving its subsidiaries, by considering a subsidiary as an entity in which the fund holds at least a $50 \%$ ownership stake (Bernstein et al., 2013). We select only achieved deals in our database (we exclude rumors and agreements).
} 
Temasek's investments grew dramatically from 2004 to 2008 with fast-growing influxes of revenue. The number of Temasek's transactions reached a peak in 2005, with 37 investments representing about $13 \%$ of the total of the transactions over the whole period. Despite the crisis, the volume of investment activity remained substantial (with an average value of 410 million USD between 2007 and 2010).

While existing literature suggests that institutional investors have a preference to invest in large and publicly held firms when investments are international (e.g. Dahlquist and Robertson, 2001), data on Temasek investments reported in Table 3 tend to moderate this view as it shows that this fund invested in many privately held firms internationally: on the 229 cross-border investments realized by Temasek, 94 were in listed firms whereas 135 have been made in unlisted companies. These figures show that Temasek used to invest in riskier investments. ${ }^{8}$ In the same way, on the 229 cross-border stakes, 122 have been less than $10 \%$ of target shares, 87 between $10 \%$ and $50 \%$ and 20 more than 50\%. The figures also show that Temasek has followed an investment strategy that can be deemed as aggressive (more than half investments are majority stakes). For example, very recently, in March 2014, Temasek has bought 24.9\% in Asian retailer A.S. Watson for about 5-7\$ billion. This purchase is "part of Temasek's aggressive reshaping of its $\$ 170$ billion portfolio to ensure higher returns by increasing its exposure to unlisted companies" (Reuters, March, 21, 2014).

Table 3: Annual Distribution of Temasek number of investments

\begin{tabular}{|c|c|c|c|c|c|c|c|c|}
\hline & $\begin{array}{c}\text { All } \\
\text { Invest. }\end{array}$ & $\begin{array}{l}\text { Foreign } \\
\text { Invest. }\end{array}$ & $\begin{array}{c}\text { Domestic } \\
\text { Invest. }\end{array}$ & $\begin{array}{l}\text { Share } \\
{[0 ; 10[}\end{array}$ & $\begin{array}{l}\text { Share } \\
{[10 ; 50[}\end{array}$ & $\begin{array}{c}\text { Share } \\
{[50 ; 100]}\end{array}$ & $\begin{array}{l}\text { Listed } \\
\text { Firms }\end{array}$ & $\begin{array}{c}\text { Unlisted } \\
\text { Firms }\end{array}$ \\
\hline 1990 & 1 & 1 & 0 & 1 & 0 & 0 & 1 & 0 \\
\hline 1991 & 2 & 2 & 0 & 0 & 2 & 0 & 1 & 1 \\
\hline 1992 & 6 & 0 & 6 & 0 & 0 & 0 & 0 & 0 \\
\hline 1993 & 2 & 1 & 1 & 1 & 0 & 0 & 0 & 1 \\
\hline 1994 & 2 & 2 & 0 & 0 & 2 & 0 & 0 & 2 \\
\hline 1995 & 7 & 4 & 3 & 0 & 4 & 0 & 0 & 4 \\
\hline 1996 & 8 & 5 & 3 & 1 & 2 & 2 & 0 & 5 \\
\hline 1997 & 11 & 9 & 2 & 3 & 6 & 0 & 4 & 5 \\
\hline 1998 & 3 & 2 & 1 & 1 & 0 & 1 & 0 & 2 \\
\hline $\begin{array}{l}1999 \\
\end{array}$ & 9 & 6 & 3 & 2 & 2 & 2 & 1 & 5 \\
\hline 2000 & 24 & 21 & 3 & 11 & 8 & 2 & 4 & 17 \\
\hline 2001 & 5 & 3 & 2 & 0 & 2 & 1 & 0 & 3 \\
\hline 2002 & 10 & 4 & 6 & 3 & 0 & 1 & 0 & 4 \\
\hline 2003 & 17 & 12 & 5 & 6 & 3 & 3 & 6 & 6 \\
\hline 2004 & 30 & 23 & 7 & 19 & 3 & 1 & 13 & 10 \\
\hline 2005 & 37 & 33 & 4 & 21 & 11 & 1 & 15 & 18 \\
\hline 2006 & 31 & 28 & 3 & 13 & 13 & 2 & 11 & 17 \\
\hline 2007 & 30 & 24 & 6 & 12 & 10 & 2 & 12 & 12 \\
\hline 2008 & 22 & 20 & 2 & 15 & 4 & 1 & 7 & 13 \\
\hline 2009 & 8 & 5 & 3 & 3 & 2 & 0 & 4 & 1 \\
\hline 2010 & 26 & 24 & 2 & 10 & 13 & 1 & 15 & 9 \\
\hline Total & 291 & 229 & 62 & 122 & 87 & 20 & 94 & 135 \\
\hline
\end{tabular}

Table 4 reports the geographical distribution of Temasek's cross-border investments by sorting the 75 target firms countries into 14 regions, the geographical distribution of cross-border stakes in listed and unlisted firms as well as the percentage of stakes in listed firms (less than $10 \%$, between $10 \%$ and $50 \%$ and more than $50 \%$ ) in each region.

The data show that the main destination of Temasek's foreign equity investments is Far East ((31\% of total cross-border investments) followed by Indian Subcontinent (18\%), North America (17\%), South Asia (14\%) and West Europe (9\%). These figures clearly reveal a tendency of the fund to diversify geographically

\footnotetext{
${ }^{8}$ Investment in unlisted firms is riskier than investment in listed firms, as private firms are generally smaller, less stable, their securities are less liquid and the value of these firms are more difficult to evaluate, due to information asymmetry related to a lack of disclosure (Metrick and Yasuda, 2011).
} 
its cross-border equity investments. A second clear trend is the tendency of the Singaporean fund to take majority stakes in South Asia: $75 \%$ of cross-border investments done in the fund's own geographical region are majority stakes. This can be explained by the fact that SWFs will prefer to invest in countries which present similar characteristics in order to reduce asymmetric information. This phenomenon of home and familiarity bias in decision making has been largely studied in the empirical literature on Foreign direct investments (FDIs) or trade (Anderson and Wincoop, 2003; Stulz and Williamson, 2003; Kang and Kim, 2008). All these papers conclude that managers who make the decision regarding FDIs have a strong preference to invest in countries close of theirs and with social and cultural familiarity. In particular, Coeurdacier et al. (2009) show that geographic distance is an important determinant of cross-border markers and acquisitions, especially among developing countries. Concerning SWFs, Chhaochharia and Laeven (2008) and Dyck and Morse (2011) show that cross-border SWF investment stakes are most importantly explained by geographic distance, ethnicity, language and religion.

Table 4: Geographical Distribution of Temasek's investments

\begin{tabular}{l|c||ccc||cc}
\hline Target & $\begin{array}{c}\text { Cross-border } \\
\text { Investments }\end{array}$ & Share & Share & Share \\
Region & 2 & 0 & {$[10 ; 50[$} & {$[50 ; 100]$} & $\begin{array}{c}\text { Listed } \\
\text { Firms }\end{array}$ & $\begin{array}{c}\text { Unlisted } \\
\text { Firms }\end{array}$ \\
\hline Africa & 0 & 0 & 0 & 0 & 2 & 0 \\
Caribbean WestIndies & 0 & 2 & 2 & 0 & 0 & 0 \\
Central \& South America & 4 & 0 & 0 & 0 & 2 & 2 \\
Central Asia & 0 & 11 & 0 & 0 & 0 & 0 \\
Central Europe & 11 & 2 & 1 & 0 & 0 & 1 \\
East Europe & 3 & 42 & 24 & 5 & 30 & 41 \\
Far East & 71 & 19 & 19 & 3 & 21 & 20 \\
IndianSubcontinent & 41 & 1 & 0 & 0 & 0 & 1 \\
Middle East & 1 & 27 & 9 & 3 & 12 & 27 \\
North America & 39 & 2 & 1 & 0 & 1 & 2 \\
North Europe & 3 & 8 & 19 & 5 & 14 & 18 \\
South Asia & 32 & 15 & 5 & 1 & 4 & 17 \\
West Europe & 21 & 3 & 5 & 3 & 6 & 5 \\
Oceanic Basin & 11 & 122 & 87 & 20 & 94 & 135 \\
\hline Total & 229 & & & & \\
\hline
\end{tabular}

\subsection{Explanatory variables}

We turn now to the choice and measurement of the explanatory variables. These are summarized in Table 5 and discussed in more detail in the following sections. 


\subsubsection{Investment decision: $W$ variables}

The investment decision strategy is a complex process that displays several dimensions. A first important dimension concerns the determinants of the investment decision: What motivates a fund to invest? As mentioned in section 2.2, there is an extensive literature based on the determinants on SWFs investment decision. Some papers try to connect the investment's decision with the characteristics of the target countries, by investigating in particular the factors driving SWF investment in foreign target countries (Chhaochharia and Laeven, 2008; Avendaño and Santiso, 2009; Bernstein et al., 2013; Avendano, 2010; Karolyi and Liao, 2010) while other empirical studies have stressed the link between the characteristics of the fund and its investment decision (Knill et al., 2012a; Megginson et al., 2013).

Relating to this literature, we use macroeconomic variables of the fund's country, Singapore, along with information from the rest of the world as determinants of the Temasek's investment decision abroad. More specifically, we include a set of variables depicting the economic development of the fund's country, that's the GDP growth (GDP Growth) as a measure of the country's wealth, the change in foreign exchange reserves (Exchange Reserv.Growth) known as the first source of capital for Temasek, the debt growth of Singapore (Debt Growth) as well as the the stability of inflation (Inflation Stab.). As SWFs use financial motives in their investment decision (Bernstein et al., 2013; Karolyi and Liao, 2010; Knill et al., 2012a; Megginson et al., 2013), the financial aspect is also taken into account by considering the MSCI World index (MSCI World) and the MSCI Singapore index (MSCI Singapore). We expect higher foreign exchange reserves excess or GDP growth to increase the probability on investment decision. In the same way, we expect that the more the GDP growth or inflation is low, the more the probability of investment decision will increase.

\subsubsection{Investment strategy in listed vs unlisted companies: $Z$ variables}

Once the SWF has decided to invest abroad, the second dimension considered is related to the type of firms in which these investments are realized. Following Knill et al. (2013), we model the choice of investing in listed versus unlisted foreign companies. Chhaochharia and Laeven (2008) find that SWFs have a preference to invest in countries with similar cultures to their own. Considering cultural differences as a proxy of information asymmetry, we expect higher (lesser) cultural difference to increase the probability to invest in listed (unlisted) company. As documented by Dahlquist and Robertson (2001) indeed, information asymmetry between domestic and foreign investors is larger for private equity investments than for public equity investments. We consider here that a SWF invests similarly to other institutional investors for testing this hypothesis.

Hence, we include the variables Language (language) and Geographical distance (close) as measure of cultural and geographical difference. In addition, we include the difference of governance between the SWF's country and the target country (Governance). ${ }^{9}$ Then, we code our variable as 1 if the governance

\footnotetext{
${ }^{9}$ In the same spirit, Knill et al. (2013) analyze whether SWFs are more likely to invest in private equity rather than in public
} 


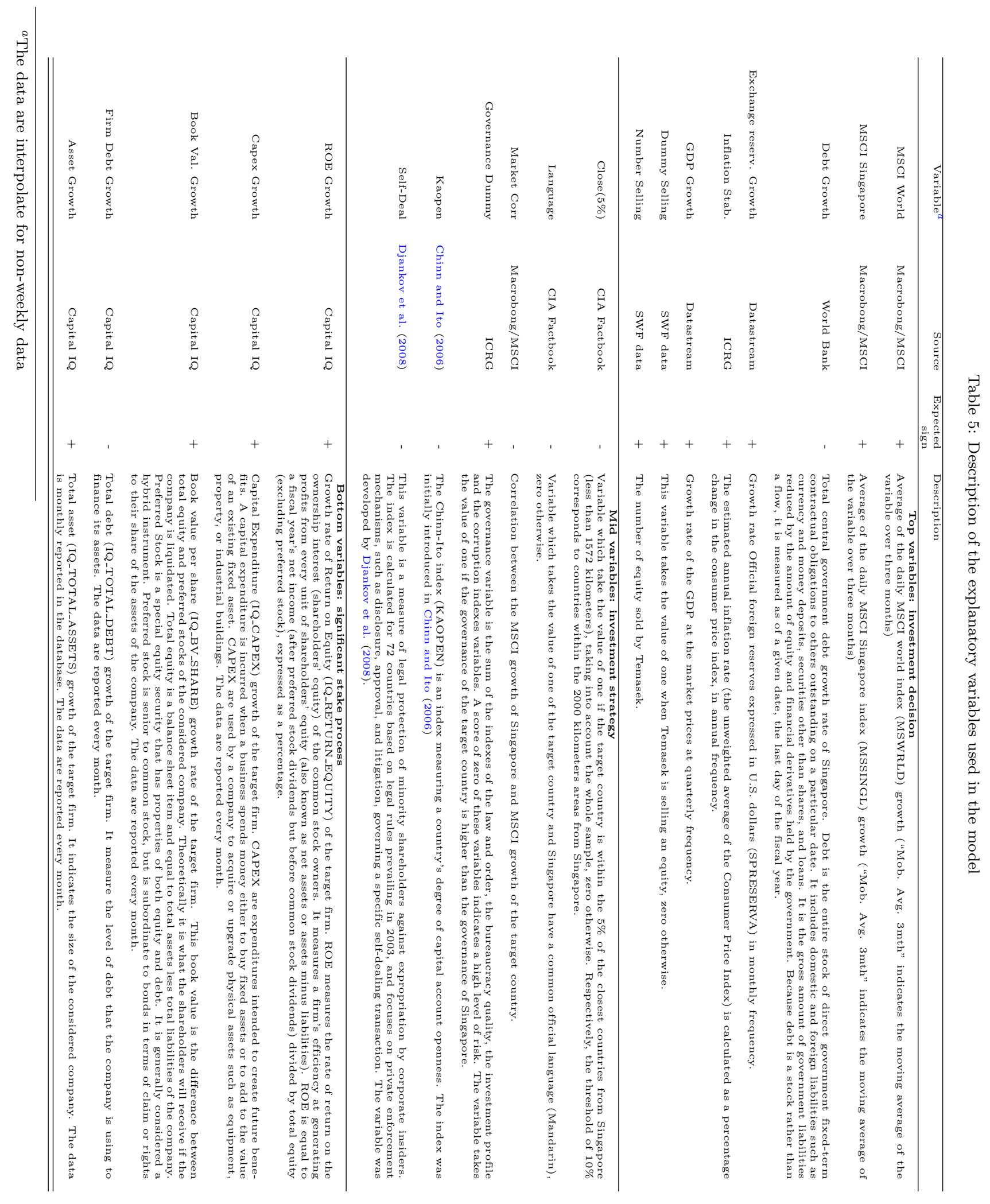


of the target country is of better quality than in Singapore and 0 otherwise. We expect this variable to be positively correlated with the probability to invest in unlisted firms. Eventually, we also include as a control the variable, 'Market correlation' (Market corr) which is the correlation between the SWF's country and target countries.

\subsubsection{Investment strategy in listed majority vs minority stakes: $X$ variables}

Once the SWF has decided to invest in cross-border listed country, it has to decide the percentage of the stake. In this node, we try to explain the motivation of Temasek to take a large stake in a listed firm by considering the financial characteristics of the target firm (ROE growth, book value growth, debt growth, asset growth) as in Bernstein et al. (2013), Heaney et al. (2011) and Knill et al. (2013). We also consider the degree of the financial openness of the target country (Kaopen variable). We should expect a positive (negative) relationship between the choice of taking a majority stake over a minority stake and the ROE, the book value and the asset (debt) growth of the firm. In a similar way, we expect that Temasek prefers to take a significant stake in a foreign listed firm when the degree of the financial openness of the target firm's country is high.

\section{Empirical part}

In the econometric model described in Model 1, we estimate jointly three nodes in a nested-logit model that allows to simultaneously identify the determinants of the investment decision, the incentives for a SWF to invest in a listed or an unlisted firm, and the variables at stake in the decision to take the control of the target firm. As already said, the estimation of a nested logit describing the various steps of the investment decision process allows their potential interdependence to be taken into account.

\subsection{Results}

The results of the nested-logit models are presented in Table 6. Column 1 reports the estimates of the full model, while columns (2) to (4) give estimates of additional regressions for the robustness check analysis. The results of the Small-Hsiao test of independence of irrelevant alternative (IIA) are displayed in Table 7.

The first important result is the rejection of the IIA assumption in Table 7, meaning that the various steps of the investment decision process considered in our analysis are interacting. This result definitely supports the choice of a nested structure. More specifically, it motivates for the use of a nested-logit approach versus a multinomial logit approach which would be misspecified. The results of the IIA test are confirmed by the significance of the inclusive values $\left(\Theta_{1}\right.$ and $\left.\Theta_{2}\right)$ in the full model (Table 6).

equity when the legal protection of minority shareholders against expropriation (measured by the "anti self-dealing" variable) of the target country is lower. 
For the sake of the interpretation, it is important to mention that the underlying utility of the first level is related to the investment outcome. It means that positive (negative) coefficients imply that an increase in the explanatory variable tends to increase (decrease) the probability of investment abroad.

As expected, we find that an increase of the exchange reserve growth influences positively the probability for Temasek to invest abroad. As documented in the literature, foreign exchange reserves are an important source of capitals for Temasek. Our results show therefore that the Temasek's investment policy is significantly responsive to a change in its funding capacity. Conversely, there is no evidence that other variables play a role in the decision to invest abroad at the notable exception of Inflation Stab. This suggests that the more the inflation is low in the country, the more the FX reserve surpluses not necessary for stabilizing inflation can be used for the cross-border investment of the fund.

As for the first level, it is important to mention that the underlying utility of the second level depends upon the decision to invest in a listed company. That is, positive (negative) coefficients imply that an increase in the explanatory variable tends to increase (decrease) the probability of intervening in a listed company and so to decrease (increase) the probability of intervening in an unlisted company.

We find that the variables language and close as measure of cultural and geographical proximity between the fund's country and the target country are negatively (positively) associated to the probability of intervening in a listed (unlisted) company. Both measures can be viewed as metrics of asymmetry of information between the target and the home country. Along these lines, our results mean that the closer the target and the home countries in terms of familiarity (proxied by common language and geographical distance), the more informed the fund will be about the target country and in turn the higher the probability to invest in an unlisted company. By contrast, if the distance is large, the fund may prefer not to take extra risk by investing in an unlisted company which generally is more opaque than listed one. These results echoe previous findings from Knill et al. (2013) according to which the probability of SWF investment in unlisted firms rather than in listed firms is negatively associated with the cultural difference between the SWF and target countries, although the authors didn't show evidence of a clear cultural bias in SWF investment with respect to the choice between private and public equity. ${ }^{10}$ It is also in line with the conclusions of Chhaochharia and Laeven (2008).

The variable Governance Dummy is negatively (positively) associated to the probability of intervening in listed (unlisted) company. This result suggests that Temasek prefers to invest abroad in private equity rather than in public equity if the target country has a better governance than in Singapore. This result corroborates in part the hypotheses tested by Knill et al. (2013) according to which the probability of SWF cross-border investment in private equity rather than public equity is positively related to the target nation's

\footnotetext{
${ }^{10}$ Knill et al. (2013) find that SWFs are less likely to invest in private companies than in public companies when the investment is cross-border. However, descriptive statistics given above on the number of cross-border investments done by Temasek in private and public firms confirm the fact that there is clearly a preference for Temasek to invest in private firms abroad.
} 
protection of investors. ${ }^{11}$

At last, we find that the probability of Temasek in private equity rather than public equity is negatively related to the stock market return correlation between Singapore and the target country.

The third level concerns the decision of taking a majority stake. A positive coefficient (negative) coefficient indicates that an increase in the explanatory variable increases (decreases) the probability of taking a large stake (more than 10\%).

We find that the probability of taking a majority stake increases when the debt growth rate of the target firm is weak, the total asset growth rate is high and when the target country is financially open. We conclude that Temasek is likely to take a large stake in growing firms with a low debt and if the target country is financially open. We see our findings as complementary to Kotter and Lel (2011), Karolyi and Liao (2010) and Avendano (2010) who argue that the SWFs' choice of the target firm is in general related to large, financially and internationally oriented and cash constrained companies. Conversely, we find no evidence that profit maximizing objectives as ROE and Capex influence the decision of Temasek.

\footnotetext{
${ }^{11}$ Knill et al. (2013) did not manage to verify this hypothesis because they find that SWFs are more likely to invest in private equity versus public equity in target nations where investor protection is low.
} 
Table 6: Nested logit estimation.

\begin{tabular}{|c|c|c|c|c|c|}
\hline \multirow{2}{*}{\multicolumn{6}{|c|}{$\begin{array}{l}(2) \\
\text { Top variables: investment decision } \\
\text { probability of investment }\end{array}$}} \\
\hline & & & & & \\
\hline Constant & $\begin{array}{c}-6.209^{* * *} \\
{[1.45]}\end{array}$ & $\begin{array}{c}-5.662^{* * *} \\
{[1.38]}\end{array}$ & $\begin{array}{c}-6.202 * * * \\
{[1.45]}\end{array}$ & $\begin{array}{c}-4.678^{* * *} \\
{[1.02]}\end{array}$ & $\begin{array}{c}-7.503 * * * \\
{[1.76]}\end{array}$ \\
\hline $\begin{array}{l}\text { MSCI World } \\
\text { Mob. Avg. } 3 \mathrm{mth}\end{array}$ & $\begin{array}{l}0.2251 \\
{[0.424]}\end{array}$ & $\begin{array}{l}0.0548 \\
{[0.414]}\end{array}$ & $\begin{array}{l}0.2266 \\
{[0.425]}\end{array}$ & $\begin{array}{l}0.2043 \\
{[0.344]}\end{array}$ & $\begin{array}{l}0.6321 \\
{[0.522]}\end{array}$ \\
\hline $\begin{array}{l}\text { MSCI Singapore } \\
\text { Mob. Avg. 3mth }\end{array}$ & $\begin{array}{c}-0.2234 \\
{[0.291]}\end{array}$ & $\begin{array}{c}-0.2629 \\
{[0.293]}\end{array}$ & $\begin{array}{l}-0.2257 \\
{[0.293]}\end{array}$ & $\begin{array}{c}-0.2052 \\
{[0.233]}\end{array}$ & $\begin{array}{c}-0.6611^{*} \\
{[0.348]}\end{array}$ \\
\hline Debt Growh & $\begin{array}{l}0.0622 \\
{[0.147]}\end{array}$ & $\begin{array}{l}0.0403 \\
{[0.143]}\end{array}$ & $\begin{array}{l}0.0623 \\
{[0.147]}\end{array}$ & $\begin{array}{l}0.0324 \\
{[0.125]}\end{array}$ & $\begin{array}{c}-0.0168 \\
{[0.179]}\end{array}$ \\
\hline $\begin{array}{l}\text { Exchange reserv. } \\
\text { Growth }\end{array}$ & $\begin{array}{c}0.3664^{* *} \\
{[0.146]}\end{array}$ & $\begin{array}{c}0.3393 * * \\
{[0.144]}\end{array}$ & $\begin{array}{c}0.3663^{* *} \\
{[0.146]}\end{array}$ & $\begin{array}{c}0.2505^{* *} \\
{[0.117]}\end{array}$ & $\begin{array}{c}0.3586^{* *} \\
{[0.172]}\end{array}$ \\
\hline Inflation Stab. & $\begin{array}{c}0.4255^{* * *} \\
{[0.131]}\end{array}$ & $\begin{array}{c}0.3702^{* * *} \\
{[0.123]}\end{array}$ & $\begin{array}{c}0.4246^{* * *} \\
{[0.131]}\end{array}$ & $\begin{array}{c}0.3023^{* * *} \\
{[0.0945]}\end{array}$ & $\begin{array}{c}0.5267 * * * \\
{[0.158]}\end{array}$ \\
\hline GDP Growth & $\begin{array}{l}0.2622 \\
{[0.203]}\end{array}$ & $\begin{array}{l}0.3432 \\
{[0.214]}\end{array}$ & $\begin{array}{l}0.2627 \\
{[0.203]}\end{array}$ & $\begin{array}{l}0.2140 \\
{[0.17]}\end{array}$ & $\begin{array}{c}0.5252^{*} \\
{[0.269]}\end{array}$ \\
\hline $\begin{array}{l}\text { Dummy Selling } \\
\text { Mob. Avg. } 3 \mathrm{mth}\end{array}$ & $\begin{array}{l}-0.0931 \\
{[0.477]}\end{array}$ & $\begin{array}{c}-0.1343 \\
{[0.478]}\end{array}$ & - & $\begin{array}{c}-0.0907 \\
{[0.399]}\end{array}$ & $\begin{array}{l}-0.3627 \\
{[0.618]}\end{array}$ \\
\hline $\begin{array}{l}\text { Number Selling } \\
\text { Mob. Avg. } 3 \mathrm{mth}\end{array}$ & & - & $\begin{array}{c}-0.0754 \\
{[0.439]}\end{array}$ & - & - \\
\hline \multicolumn{6}{|c|}{$\begin{array}{l}\text { Mid variables: investment strategy } \\
\text { probability of investment in listed company }\end{array}$} \\
\hline Close (5\%) & $\begin{array}{c}-1.037^{* * *} \\
{[0.356]}\end{array}$ & - & $\begin{array}{c}-1.039 * * * \\
{[0.359]}\end{array}$ & $\begin{array}{l}-0.9508^{* * *} \\
{[0.285]}\end{array}$ & $\begin{array}{c}-0.8749 * * \\
{[0.414]}\end{array}$ \\
\hline Close (10\%) & & $\begin{array}{c}-1.384 * * * \\
{[0.376]}\end{array}$ & - & - & - \\
\hline Language & $\begin{array}{c}-1.742^{* * *} \\
{[0.446]}\end{array}$ & $\begin{array}{c}-1.812^{* * *} \\
{[0.454]}\end{array}$ & $\begin{array}{c}-1.746^{* * *} \\
{[0.452]}\end{array}$ & $\begin{array}{c}-1.632 * * * \\
{[0.346]}\end{array}$ & $\begin{array}{c}-1.733 * * * \\
{[0.508]}\end{array}$ \\
\hline Market corr & $\begin{array}{c}-4.385^{* * *} \\
{[0.713]}\end{array}$ & $\begin{array}{c}-4.292 * * * \\
{[0.706]}\end{array}$ & $\begin{array}{c}-4.385 * * * \\
{[0.714]}\end{array}$ & $\begin{array}{c}-3.502 * * * \\
{[0.47]}\end{array}$ & $\begin{array}{c}-5.898^{* * *} \\
{[0.991]}\end{array}$ \\
\hline $\begin{array}{l}\text { Governance } \\
\text { Dummy }\end{array}$ & $\begin{array}{c}-1.508^{* * *} \\
{[0.311]}\end{array}$ & $\begin{array}{c}-1.53 * * * \\
{[0.311]}\end{array}$ & $\begin{array}{c}-1.508^{* * *} \\
{[0.311]}\end{array}$ & $\begin{array}{l}-0.9783^{* * *} \\
{[0.24]}\end{array}$ & - \\
\hline Kaopen & & - & - & $\begin{array}{l}-0.1482 * * * \\
{[0.0525]}\end{array}$ & - \\
\hline \multicolumn{6}{|c|}{$\begin{array}{l}\text { Bottom variables: significant stake process } \\
\text { probability of investment with a large stake }\end{array}$} \\
\hline ROE Growth & $\begin{array}{l}0.0056 \\
{[0.012]}\end{array}$ & $\begin{array}{c}0.0069 \\
{[0.0243]}\end{array}$ & $\begin{array}{l}0.0056 \\
{[0.012]}\end{array}$ & $\begin{array}{c}0.0061 \\
{[0.00931]}\end{array}$ & $\begin{array}{c}0.0068 \\
{[0.0109]}\end{array}$ \\
\hline Capex Growth & $\begin{array}{l}0.2649 \\
{[0.19]}\end{array}$ & $\begin{array}{l}0.2472 \\
{[0.22]}\end{array}$ & $\begin{array}{l}0.2649 \\
{[0.19]}\end{array}$ & $\begin{array}{c}0.5741^{* * *} \\
{[0.145]}\end{array}$ & $\begin{array}{l}0.1928 \\
{[0.144]}\end{array}$ \\
\hline $\begin{array}{l}\text { Book Val. } \\
\text { Growth }\end{array}$ & $\begin{array}{c}-0.1308 \\
{[0.388]}\end{array}$ & $\begin{array}{c}-0.1009 \\
{[0.371]}\end{array}$ & $\begin{array}{c}-0.1311 \\
{[0.388]}\end{array}$ & $\begin{array}{l}0.1638 \\
{[0.378]}\end{array}$ & $\begin{array}{c}-0.1987 \\
{[0.395]}\end{array}$ \\
\hline $\begin{array}{l}\text { Firm Debt } \\
\text { Growth }\end{array}$ & $\begin{array}{c}-1.024^{* * *} \\
{[0.307]}\end{array}$ & $\begin{array}{c}-1.085 * * * \\
{[0.312]}\end{array}$ & $\begin{array}{c}-1.024 * * * \\
{[0.307]}\end{array}$ & $\begin{array}{c}-0.9042^{* * *} \\
{[0.245]}\end{array}$ & $\begin{array}{c}-1.167^{* * *} \\
{[0.324]}\end{array}$ \\
\hline Asset Growth & $\begin{array}{c}2.355 * * * \\
{[0.711]}\end{array}$ & $\begin{array}{c}2.331 * * * \\
{[0.744]}\end{array}$ & $\begin{array}{c}2.354 * * * \\
{[0.711]}\end{array}$ & $\begin{array}{c}2.078^{* * *} \\
{[0.571]}\end{array}$ & $\begin{array}{c}2.207 * * * \\
{[0.744]}\end{array}$ \\
\hline kaopen & $\begin{array}{c}0.7708^{* * *} \\
{[0.199]}\end{array}$ & $\begin{array}{c}0.774^{* * *} \\
{[0.2]}\end{array}$ & $\begin{array}{c}0.7709^{* * *} \\
{[0.199]}\end{array}$ & - & $\begin{array}{c}0.6076^{* *} \\
{[0.284]}\end{array}$ \\
\hline $\begin{array}{l}\text { Governance } \\
\text { Dummy }\end{array}$ & & - & - & - & $\begin{array}{l}1.0770 \\
{[0.904]}\end{array}$ \\
\hline$\Theta 2$ & $\begin{array}{c}0.8033^{* * *} \\
{[0.181]}\end{array}$ & $\begin{array}{c}\text { Inclu } \\
0.7791^{* * *} \\
{[0.176]}\end{array}$ & $\begin{array}{c}\text { ve values } \\
0.8029^{* * *} \\
{[0.181]}\end{array}$ & $\begin{array}{c}1.017^{* * *} \\
{[0.2]}\end{array}$ & $\begin{array}{l}0.6869 * * * \\
{[0.151]}\end{array}$ \\
\hline$\Theta 1$ & $\begin{array}{c}5.987 * * * \\
{[0.827]}\end{array}$ & $\begin{array}{c}6.782^{* * *} \\
{[0.947]}\end{array}$ & $\begin{array}{c}5.987 * * * \\
{[0.831]}\end{array}$ & $\begin{array}{c}5.677^{* * *} \\
{[0.776]}\end{array}$ & $\begin{array}{c}5.319^{* * *} \\
{[0.681]}\end{array}$ \\
\hline Likelihood & -307.2914 & -296.6666 & -307.2956 & -311.5711 & -340.4434 \\
\hline
\end{tabular}


Table 7: IIA test, pvalue, column (1) in the table 6

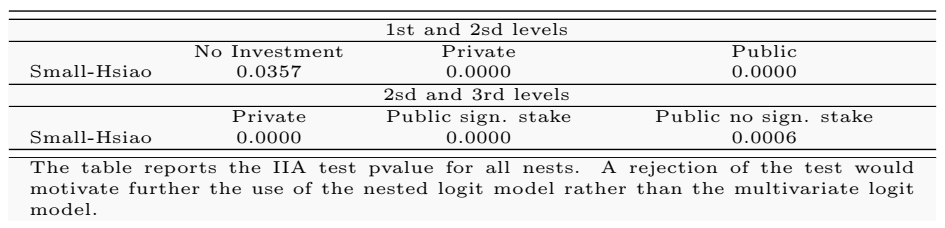

\subsection{Additional Variables}

To assess the robustness of our findings, we have conducted a set of auxiliary estimations. The results are displayed from columns (2) to (5) in Table 6. In the first model, we propose an alternative definition for the variable close which is computed in its new version as 1 if the target country is located 2000 miles away from Singapore instead of 1000 miles in the benchmark specification. Second, in column (3), we use the number of stakes sold by Temasek during the past 3 months in order to capture its disinvestment activity instead of using a dummy variable. ${ }^{12}$ Third, the financial openness variable (Kaopen) is introduced in the second level of the model instead of the third one in order to capture the role of the financial liberalization on the private firm investment (see column (4)). At last, the dummy variable governance is introduced in the third nest to capture the effect of the governance quality on the share of stake taken by Temasek.

Overall, our initial findings are supported by the robustness analysis. As reported in columns 2 and 3, using an alternative definition to measure the disinvestment activity and the geographical distance does not alter our conclusions. Results in columns 4 and 5 provide us with further insight of the strategy followed by Temasek. Hence, the variable kaopen appears to be significant when inserted in the second level of the model. The financial openness of the target country is therefore relevant to explain both the decision to invest in a public or private company and the percentage of stakes invested in the company. On the other hand, the variable depicting the quality of the governance in the target country is neither significant in the second nor the third level. It turns out that the probability to invest in an unlisted company depends positively on the level of the financial openness of the target firms countries and through this variable, it appears that the decision of Temasek to take a significant stake depends positively on the Capex growth rate, which was not the case in previous regressions. Finally, we also think that the decision to take a significant stake in foreign firms could be affected by the governance of the firms' countries. The difference of governance between the target country and Singapore is strongly significant and positive. It means that the odds that Temasek takes less than $10 \%$ in a target firm increase with bureaucracy quality and the respect of the rule of the law of the target country, relatively to Singapore and when the risk of expropriation and

\footnotetext{
${ }^{12}$ We consider the number of stakes sold and not the total amount as this information is not systematically available in our database.
} 
corruption are low. This result suggest that SWFs do not seek protection by investing with a large stake in nations that provide strong investor protection.

\section{Conclusion}

This paper aims to shed light on the determinants of SWF's cross-border majority stake while considering the whole sequence of choices involved in this decision: (i) the decision to invest abroad or not, (ii) the decision to invest in a listed versus unlisted firm, and (iii) the decision to make large versus small investment in target company. To this end, we estimate a nested logit model on an original hand-collected database comprising investments made by one of the most active SWF, namely, Temasek, between 1990 and 2010. Several interesting insights emerge from our analysis. First, the data support that various decisions considered in the model interplay. Second, we find that the probability to invest increase with the FX reserves. Third, Temasek tends to favor unlisted companies when the home country and the target country are culturally more close (measured as the geographical distance and common language). A strong market correlation between the firm's target country and Singapore is also a key factor for investing in unlisted companies. Furthermore, the probability to invest in a unlisted firm increases with the difference of governance between the target country and Singapore. Fourth, we find that the probability to take a significant stake is growing up with a weak debt growth rate, a high total asset grow rate and when the firm's country is financially open. Eventually, we find no evidence that profit maximizing objectives as ROE and Capex

influence the decision of Temasek, which means that motives other than financial influence the fund in its investment decision. 
Aizenman, J. and R. Glick (2009). Sovereign Wealth Funds: Stylized Facts about their Determinants and Governance. International Finance, Blackwell Publishing 93 12(3), 351-386.

Amar, J., B. Candelon, and C. Lecourt (2015). Are sovereign wealth funds decisions based on country factors? Working paper.

Anderson, J.E. and E. Van Wincoop (2003). Gravity and gravitas: a solution to the border puzzle. American Economic Review 93(6), 170-192.

Avendano, R. (2010). Sovereign wealth fund investments: From firm-level preferences to natural endowments. Working paper, Paris School of Economics.

Avendaño, R. and J. Santiso (2011). Are Sovereign Wealth Funds Politically Biased? A Comparison with other Institutional Investors. Jean-Claude Cosset (ed.) Institutional Investors in Global Capital Markets (International Finance Review, Volume 12) Emerald Group Publishing Limited $313-3$

Balding, C. (2008). A portfolio analysis of sovereign wealth funds. Working paper, University of California, Irvine.

Beck, R. and M. Fidora (2008). The impact of sovereign wealth funds on global financial markets. Intereconomics: Review of European Economic Policy 43(6), 349-358.

Beine, M., O. Bernal, J.-Y. Gnabo, and C. Lecourt (2009). Intervention policy of the boj: A unified approach. Journal of banking \& finance

Ben-Akiva, M. and M. Bierlaire (1999). Discrete choice methods and their applications to short term travel decisions. Handbook of transportation science, $5-33$.

Bernstein, S., J. Lerner, , and A. Schoar (2013). The investment strategies of sovereign wealth funds. Journal of Economic Perspectives 27(2), 219-238..

Bortolotti, B., V. Fotak, W. Megginson, and W. F. Miracky (2010). Quiet leviathans: Sovereign wealth fund investment, passivity, and the value of the firm. Working paper.

Bortolotti, B. and W. Miracky (2009). SWF annual report 2008. Working paper.

Brière, M. and Z. Bodie (2014). Sovereign wealth and risk management: A framework for optimal asset allocation of sovereign wealth. Journal of Investment Management, 45-61.

Butt, S., A. Shivdasani, C. Stendevad, and A. Wyman (2008). Sovereign wealth funds: A growing global force in corporate finance. Journal of Applied Corporate Finance 20(1), 73-83.

Chhaochharia, V. and L. Laeven (2008). Sovereign wealth funds: Their investment strategies and performance. $C E P R$ Discussion Paper (6959).

Chinn, M. D. and H. Ito (2006). What matters for financial development? capital controls, institutions, and interactions. Journal of Development Economics 81(1), 163-192.

Clark, G. L. and A. H. Monk (2009). The oxford survey of sovereign wealth funds' asset managers. Working paper university of Oxford.

Coeurdacier, N., De Santis, R. and A. Aviat (2009) Cross-border mergers and acquisitions: financial and institutional forces. Economic Policy, CEPR; CES; MSH, 24 55-106.

Dahlquist, M. and G. Robertson (2001). Direct foreign ownership, institutional investors, and firm characteristics. Journal of Financial Economics 59, 413-440.

Davis, J., R. Ossowski, J. Daniel, and S. Barne (2003). Stabilization and savings funds for nonrenewable resources: experience and scale policy implications. In Jeffrey Davis, Rolando Ossowski and Annalisa Fedelino (eds). Fiscal Policy Formulation and Implementation in Oil-Producing Countries. International Monetary Fund, Washington, DC: Chapter 11 .

Dewenter, K. L., X. Han, and P. Malatesta (2010). Firm values and sovereign wealth fund investments. Journal of Financial Economics 98(2), 256-278.

Djankov, S., R. LaPorta, F. Lopez-de Silanes, and A. Shleifer (2008). The law and economics of self-dealing. Journal of Financial Economics 88(11883), 430-465.

Dyck, A. and A. Morse (2011). Sovereign wealth fund portfolios. Working paper University of Chicago (2011-003).

Fasano, U. (2000). Review of the experience with oil stabilization and savings in selected countries. IMF Working paper $W P / 00 / 112$.

Fernandes, N. (2011). Sovereign wealth funds: Investment choices and implications around the world. Working paper.

Fotak, V., B. Bortolotti, W. Megginson, and W. Miracky (2008). The financial impact of sovereign wealth fund investments in listed companies. Working paper.

Hau, H. (2001a). The geography of financial markets: Geographic patterns of trading profitability in xetra. European Economic Review 45, 757-769.

Hau, H. (2001b). Location matters: An examination of trading profits. Journal of Finance 56, $1959-1983$.

Heaney, R., L. R., and V. V. (2011). Sovereign wealth fund investment decisions:temasek holdings. Australian Journal of Management 36, 109-120.

Hesse, H. and T. Sun (2009). Sovereign wealth funds and financial stability-an event study analysis. IMF Working paper $9(09 / 239), 239$.

Kang, J.K and J.M. Kim (2008) The geography of block acquisitions Journal of Finance 63, 2817-2858.

Karolyi, G. and R. C. Liao (2010). What is different about government-controlled acquirers in cross-border acquisitions? Working paper University of Cornell (2010.38).

Knill, A., S. A. Johan, and N. Mauck (2013). Determinants of sovereign wealth fund investment in private equity vs public equity. Journal of International Business Studies 44(2), 155-172.

Knill, A., B.-S. Lee, and N. Mauck (2012a). Bilateral political relations and sovereign wealth fund investment. Journal of Corporate Finance 18(1), 108-123.

Knill, A. M., B. S. Lee, and N. Mauck (2012b). Sovereign wealth fund investment and the return-to-risk performance of target firms. Journal of Financial Intermediation 21(2), 315-340. 
Kotter, J. and U. Lel (2011). Friends or foes? target selection decisions of sovereign wealth funds and their consequences. Journal of Financial Economics 101(2), 360-381.

Lyons, G. (2007). State capitalism: The rise of sovereign wealth funds. Journal of Management Research 7(3), $119-146$.

Medas, P. A. and E. Le Borgne (2007). Sovereign wealth funds in the pacific island countries; macro-fiscal linkages. IMF Working paper $(07 / 297)$.

Megginson, W. L., B. Bortolotti, V. Fotak, and W. Miracky (2009). Sovereign wealth fund investment patterns and performance. Working paper (2009.22).

Megginson, W. L., M. You, and L. Han (2013). Determinants of sovereign wealth fund cross-border investments. The Financial Review 48(4), 539-572.

Metrick, A. and A. Yasuda (2011). Venture capital and other private equity: a survey. European Financial Management 17(4), 619-654.

Miceli, V. (2013). Do sovereign wealth funds herd in equity markets? Quantitative Finance 13(10), 1503-1518.

Miracky, W., F. Drosten, D. Dyer, T. Goldner, L. Lagarde, and V. Piedrahita (2008). Assessing the risks: the behaviors of sovereign wealth funds in the global economy. Working paper.

Raymond, H. (2009). The effect of sovereign wealth funds' investments on stock markets. EconomiX Working paper 38.

Raymond, H. (2010). Sovereign wealth funds as domestic investors of last resort during crises. International Economics 123(123), 121-160.

Small, K. and C. Hsiao (1985). Multinomial logit specification tests. International Economic Review 26, 619-627.

Stulz, R. and R. Williamson (2003) Culture, openness and finance. Journal of Financial Economics 70, 313-349. 